\title{
MARKETING DECISION-MAKING IN HUNGARIAN SMES
}

\section{MARKETINŠKE ODLUKE U MAĐARSKIM MALIM I SREDNJIM PODUZEĆIMA}

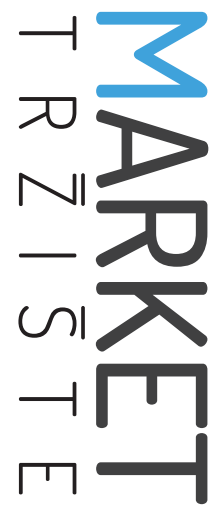

Market-Tržište

Vol. 31, No. 1, 2019, pp. 39-59

UDK 658.8:65.017.2/.3(439)

DOI http://dx.doi.org/10.22598/mt/2019.31.1.39

Preliminary communication

\author{
Mirkó Gáti ${ }^{a}$, András Bauer ${ }^{b}$ \\ a Corvinus University of Budapest, Fővám tér 8., H-1093 Budapest, HUNGARY, e-mail: mirko.gati@uni-corvinus.hu \\ b Corvinus University of Budapest, Fővám tér 8., H-1093 Budapest, HUNGARY, e-mail: andras.bauer@uni-corvinus.hu
}

\begin{abstract}
Purpose - Small and medium-sized enterprises (SMEs) play an important role in the economy, in both national and international markets. These organizations work under different conditions, possess different capabilities, and therefore have a different approach to certain company functions (e.g., marketing). SMEs define their marketing activity within a scope that differs from their large counterparts. Our aim is to provide a better understanding of certain influencing factors that are the antecedents to the understanding of an SME's marketing activities.
\end{abstract}

Design/Methodology/Approach - Since relatively little has been written on these effects, we decided to use a qualitative approach because of both the sample (SMEs) and the research problem. The SME marketing activity was analyzed from an exploratory perspective, with the research conducted in the form of in-depth interviews in 15 SMEs. We had the opportunity to analyze our research questions in a Hungarian context.

Findings and implications - As a result, some influencing patterns emerged, such as the deciding role of the SME leader, strong customer focus, the ability to adapt to the market, and innovative, entrepreneurial characteristics. The results can help both theoretical researchers of SME marketing and SME marketing practitioners.

Limitations - The limitations of this paper lie in the sample size and structure, and in the limitations of qualitative methodology.

Originality - Despite limitations, the influencing factors that emerged have not been analyzed in prior empiri-

\section{Sažetak}

Svrha - Mala i srednja poduzeća (SME) imaju važnu ulogu u gospodarstvu na nacionalnim i međunarodnim tržištima. Ove organizacije posluju u različitim uvjetima, posjeduju različite sposobnosti i zbog toga imaju drugačiji pristup određenim funkcijama u poduzeću (npr. marketingu). Svoju marketinšku aktivnost one definiraju u drugačijem opsegu u usporedbi sa svojim većim konkurentima. Cilj rada jest omogućiti bolje razumijevanje određenih utjecajnih čimbenika koji su prethodnici za razumijevanje marketinških aktivnosti malih i srednjih poduzeća.

Metodološki pristup - $\mathrm{S}$ obzirom na relativno malo prethodnih istraživanja o ovim učincima, odlučilo se za primjenu kvalitativnog pristupa, i zbog uzorka (malih i srednjih poduzeća) i zbog problema istraživanja. Marketinška aktivnost malih i srednjih poduzeća analizirana je kroz izviđajnu perspektivu; provedeno je 15 dubinskih intervjua u malim i srednjim poduzećima. Istraživačka pitanja analizirana su u kontekstu mađarskog tržišta.

Rezultati i implikacije - Kao rezultat pojavili su se neki obrasci utjecaja, poput odlučujuće uloge lidera malog i srednjeg poduzeća, snažne usredotočenosti na potrošača, sposobnosti prilagodbe tržištu i inovativne poduzetničke karakteristike. Rezultati mogu pomoći i znanstvenicima i stručnjacima u praksi u području marketinga malih i srednjih poduzeća.

Ograničenja - Ograničenja istraživanja odnose se na veličinu i strukturu uzorka te na ograničenja kvalitativne metodologije.

Doprinos - Unatoč ograničenjima istraživanja, otkriveni utjecajni čimbenici nisu analizirani u prethodnim empi- 
cal studies in terms of SMEs' decision-making factors in the context of online marketing and use of social media tools. By answering our research questions, we can provide a better explanation of how marketing decisions are made by SMEs.

Keywords - small and medium-sized enterprises, small and medium-sized enterprise marketing, small and medium-sized enterprise marketing decisions, the scope of small and medium-sized enterprise marketing, qualitative in-depth interviews rijskim istraživanjima o čimbenicima odlučivanja u malim i srednjim poduzećima u kontekstu online marketinga i korištenja alata društvenih mreža. Odgovarajući na istraživačka pitanja pruženo je bolje objašnjenje o tome kako se donose marketinške odluke u malim i srednjim poduzećima.

Ključne riječi - mala i srednja poduzeća, marketing u malim i srednjim poduzećima, marketinške odluke $u$ malim i srednjim poduzećima, opseg marketinga malih i srednjih poduzeća, kvalitativni dubinski intervjui 


\section{INTRODUCTION}

In observing the marketing activity of small and medium-sized enterprises (SMEs), researchers do not necessarily face the same problems as in the case of large companies. They cannot solve SMEs' problems if by applying the same methods they use during the analysis of large companies. The marketing of SMEs is a marketing practice that affects the market of a limited scope, it operates with the contribution of the owner/ manager, builds on limited resources, and lacks specialist marketing knowledge (Gamble, Gilmore, McCartan-Quinn \& Durkan, 2011).

If the economic significance of SMEs is as important as pointed out by statistics, it gives rise to the question as to the competitive advantage of these companies which differentiates them from their competitors. In several industries, the competitive disadvantage of SMEs vs. large companies may be compensated by the spread of the Internet and social media (Bocconcelli, Cioppi \& Pagano, 2017) or simply by the conscious and focused application of the marketing activity (Murphy, Celuch \& Callaway, 2015). SMEs do not yet use Internet-based solutions professionally for their marketing activities (Akunuri, 2011). However, the Internet makes it possible for SMEs serving niche markets to be visible for customers who are really interested in their products and/or services. Based on the perception of SME leaders, it can be concluded that a web presence in itself does not necessarily mean benefits for a firm (Fehér, 2012). In order to take advantage of these presumptions, SMEs must take a more conscious approach towards them, often by devoting sufficient energy and money to mastering certain techniques so as to not to compromise their competitive position on the market. If firms do not devote sufficient resources to these solutions, the solution intended to ensure competitive advantage could become a competitive disadvantage due to the difficulties encountered in introducing the solution. In other cases, it can be difficult to determine afterwards how much of the investment made in the attempted solution (e.g., the creation of a Facebook brand page in addition to an existing webpage) has been lost (cost-effectiveness issue) due to bad, insufficiently founded measurement procedures. All these risks depend largely on the IT competence of an SME's leaders, their networking knowledge and ambitions, as well as their proactive attitude towards marketing. Like everything else, the buck stops with the owner-manager - the success of the online entrepreneurial marketing activity will depend on the entrepreneur's IT and entrepreneurial capacity to proactively use the online platform in building extensive networks of wide and varied key contacts (Akunuri, 2011: p. 189).

The findings of Bocconcelli and others (2017) are mainly based on case study research which interprets the marketing activities of a specific company. As a further step, we conducted indepth interviews with 15 SME owners/managers. Having reached a theoretical saturation, we summarized their interpretation of marketing to provide a framework for identifying the factors that determine the choice of different marketing solutions of SMEs (e.g., classic or innovative online marketing solutions). As online marketing, social media, and the related professional decision-making in SMEs are still in an introductory phase, we hope to shed light on these factors.

\section{LITERATURE REVIEW}

Both SMEs and researchers must be aware of the influencing factors that determine the marketing activity they perform (Möller \& Anttila, 1987; Walsh \& Lipinski, 2009). In this paper, we concentrate on the role of internal factors, although certain external factors (e.g., industry type or level of competition) may also influence SMEs' marketing activities.

The role of marketing within a company has been the focus of several studies (Moorman \& Rust, 1999; Gyulavári \& Kolos, 2015). While decisions in large organizations are mostly implemented within a structured framework and under clear, hierarchical circumstances, in SMEs these processes often start with the entrepre-

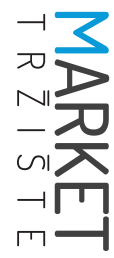




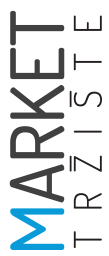

neur providing a vision or goal for the organization. The personality and style of the company leader greatly influence decision-making in SMEs, but can sometimes lead to a narrow, short-term interpretation of marketing (Bodlaj \& Rojšek, 2014). Since there is often no established management structure in SMEs, and marketing-like activities usually depend on individual decisions, the company leader (owner/manager) has a very important role. This confirms the presupposition for the examination that SME marketing activities depend largely on the individual characteristics of their owner/manager. The personal solutions of SME leaders to a given problem affect the effectiveness of marketing in an organization (Gamble et al., 2011; Kaszás, Péter, Keller \& Kovács, 2016).

Some previous studies concentrated on the personality of SME leaders (Sidik, 2012), while others focused on their personal motivating factors (Herrmann \& Nadkarni, 2014), but from the point of view of this article, it is primarily the personal characteristics/competencies that form part of the scope of observation (Buzulukova, 2013).

From the practical standpoint of SME marketing, the entrepreneurial approach (Buzulukova, 2013), the innovative nature (Hooley, Greenley, Cadogan \& Fahy, 2005), the ability to identify and take advantage of (market) opportunities (Covin \& Slevin, 1989), and the network approach (Bocconcelli et al., 2016) are essential. Furthermore, the ability to look ahead proactively, the ability to accept and take risks, and the ability to efficiently handle limited resources are also important (Aaltonen, 2013). Creating market opportunities requires fast learning, perseverance in the face of initial difficulties, and the ability to take advantage of unforeseen events. This requires SMEs to adopt an intuitive decision-making process to take the necessary steps towards the known aim, even if the information they have to hand is incomplete (Mort, Weerawardena \& Liesch, 2012). In SME marketing, creating opportunity is a continuous, active, and integral part of the decision-making process, one that affects the way in which marketing tools are used. The internal corporate characteristics related to the ability to create new opportunities are entrepreneurship orientation and the ability to adapt to the market.

By entrepreneurship orientation we mean the innovative skills by which new and uncertain products and services are produced and delivered, and the conquest of new markets made possible when the SME faces new market opportunities (Buzulukova, 2013). It consists of three main elements: an innovative nature, a proactive nature, and the ability to take risks. An innovative nature describes the extent of new ideas, novelties, experimentation, and creativity. A proactive nature describes the activity of the given SME in light of future market changes. Risk-taking captures the SME leader's intention for risky resource allocation. Covin and Slevin (1989) measured entrepreneurship orientation through opportunity recognition, growth orientation, and organizational learning. Entrepreneurship orientation can facilitate the development of new products and services, the conquest of new markets, and new conditions of growth (Zortea-Johnston, Darroch \& Matear, 2012), thereby making the given SME capable of applying new tools in its operation through quick adaptation.

Entrepreneurship orientation is related to opportunity creation and the ability to adapt to the market through the innovative nature, risk-taking, and proactive activity patterns (Covin \& Slevin, 1989). Market innovation is an important factor in the marketing activity of an SME. To achieve creative and innovative results, it may be necessary to use unsophisticated marketing tools in an experimental context, in which risk-taking is an indispensable factor (Aaltonen, 2013). The innovative combination of resources can serve as a very useful opportunity, for example in relation to online marketing activities (Mort et al., 2012) for testing and successfully applying novel marketing tools. SMEs with a higher level entrepreneurship orientation are not only interested in testing novel products and services, but also aim at changing their ex- 
isting usage behavior (Zortea-Johnston et al., 2012), even with the help of novel marketing communication tools.

The nature of the marketing tools used can be affected by resources, competencies, capabilities, and cultural elements, but also by (managerial) attitude, and network approach (Durkin, McGowan \& McKeown, 2013). Furthermore, firm age and industry can influence both the overall performance and the marketing performance (Blackburn, Hart \& Wainwright, 2013). The SME marketing activity is therefore influenced by certain factors that are largely related to the owner/manager. Some of these individual factors may affect the marketing activity (both SME-specific and online) of the given SME. SME leaders typically base their decision-making on intuition and on their personal networks (Mort et al., 2012), which are used to build customer relationships. The introduction of new ideas, innovations, a fast decision-making system, and managerial decisions made in line with the limited resources available are facilitated by decisions often made in accordance with personal contact networks (Aaltonen, 2013). The attitude of SME leaders towards marketing and the co-ordination of marketing activities are important factors (Hooley et al., 2005). Morgan (2012) mentions the company leaders' role as a marketing resource within the human resource factors they identified. In relation to the use of various marketing tools, SMEs are internally driven; therefore, the company leader's control over the SME processes also needs to be examined (Mort et al., 2012).

Marketing resources could be said to be among the most important influencing factors, which primarily consist of different marketing tools especially marketing mix-related tools - and marketing skills (Merrilees, Rundle-Thiele \& Lye, 2011; Gyulavári \& Kenesei, 2012; Malota, 2015).

Merrileesand others (2011) match marketing skills with marketing communication tools within overall marketing tools. SMEs often apply adapted variants of offline and online market- ing communications tool sets. The application of online and social media marketing communication at the tactical marketing tool level also requires an innovative marketing communication approach (Aaltonen, 2013), where the values created by the customers are often involved in the marketing activities. Marketing skills are therefore the factors that create synergy between the tools and make it possible to gain corporate advantage. Consequently, capabilities embody the practical knowledge and the collective learning within the enterprise to ensure the high-level co-ordination of the functional activities in the organization (Hooley, Greenley, Broderick \& Rudd, 2004).

Specialist marketing skills cover the marketing function (Morgan, 2012). Tactical marketing programs - which are mainly based on the classic marketing mix - are the backbone of specialist marketing skills (Vorhies \& Morgan, 2005). Thus, for example, advertising, social media participation, sponsorship, and PR are marketing communication skills belonging to this category. In a new marketing communication environment, the various online marketing tools (e.g., corporate web page, online forum) make marketing communication skills even more important in SME marketing. SME marketing communication skills emphasize the roles of creativity and relationships, and the importance of sales and networks for SMEs (Aaltonen, 2013).

Apart from the existence of different capabilities related to the marketing function, it is also worth considering the processes and cultural characteristics of the organization that can influence the marketing tool used by SMEs. Marketing exists less and less as a standalone function; rather, it is a management philosophy or orientation exercised within the organization, one that is increasingly indispensable for the success of the organization (Moorman \& Rust, 1999). At the same time, the relationship between marketing skills and market orientation is symbiotic (Morgan, 2012). Furthermore, according to Zortea-Johnston and others (2012) and Aaltonen (2013), entrepreneurial orientation and market

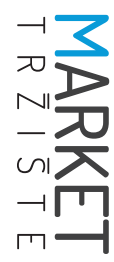




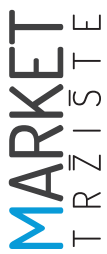

orientation jointly contribute to innovative solutions, mainly in an SME context.

In the following section, among the important strategic orientations for SMEs, market orientation is emphasized. Narver and Slater (1990) describe market orientation as a construct consisting of three basic elements: customer orientation, competitor orientation, and interfunctional coordination. These elements form part of the universal organizational culture (Homburg \& Pflesser, 2000). According to Narver and Slater (1990), a market-oriented enterprise is an organization characterized by both competitor orientation and co-ordination between the organizational units. Generally, market orientation describes the understanding of customer needs, the application of processes according to customer needs, and the answers to market changes (Zortea-Johnston et al., 2012). While a market-oriented SME might not introduce as many radical innovations as a less market-oriented enterprise, with respect to the introduction of market-led innovations, it does not lag behind entrepreneurship-oriented SMEs. With the help of market orientation, SMEs often get closer to their consumers (as compared to large enterprises), and are better at incorporating innovations into their developments (Merrilees et el., 2011). Nevertheless, market orientation is a deeply embedded cultural resource, which, besides management skills and market-based resources, is an important influencing factor in the marketing activity.

Regarding the use of market orientation as a severe criticism, Gruber (2004: p. 175) remarks that "several models of small firm marketing incompletely describe the development of marketing in growing firms, because they miss out the main step of opportunity recognition, for which the market-oriented behavior is indispensable." Entrepreneurship orientation and the ability to adapt to the market are considered in order to obtain a more complete picture of the influencing factors of marketing tool use, because SME marketing requires an innovative spirit, combined with market sensitivity.
According to the resource-based theory (Hansen \& Wernerfelt, 1989), the role of organizational factors takes prime position ahead of Porter's determinism of the industrial approach (which emphasizes the primacy of the sectoral situation and external analysis). Other organizational factors are resources (i.e., the totality of tools), capabilities, organizational processes, corporate characteristics, information, and knowledge (Hooley et al., 2005). Many resources behind marketing activity can create potential corporate advantage, since marketing tools see resource-based theory - are resources that accumulate in the enterprise over time. Morgan (2012) emphasizes the importance of human factors and tools. Thus, tool use is utilized in the framework of this article, and the importance of the human factor is treated as a priority issue, taking into account the unique nature of SMEs.

In our analysis, we address the use of online marketing tools, including different types of social media. While the use by larger companies use social media in their marketing processes is well-documented (Andzulis, Panagopoulos \& Rapp, 2012; Trainor, Andzulis, Rapp \& Agnihotri 2014) and some evidence from SMEs exists (Michelidou, Siamagka \& Christodoulides, 2011), these sources provide only limited explanations of what influences SME leaders in their decisions. Bocconcelli and others (2017) explain how SMEs can create competitive advantage by using different social media outlets, but this explanation is only based on a case study. Linking other variables, such as market orientation, or the SME leader's experience in online communication, can shed more light on their decision-making process.

\section{RESEARCH QUESTIONS}

The aim of this research is to determine the factors which may have an influence on marketing activities applied by an SME.

After presenting the theoretical relationships, the research questions - which consist of the concepts, theories, and connections presented 
in the literature review - are now formulated (RQX, where $X=1,2, \ldots$ n).

Based on the literature review, it is interesting to note which marketing activity SMEs are likely to perform as a consequence of risk tolerance and willingness to innovate (entrepreneurial orientation); recognition of opportunities (ability to adapt); the marketing-related attitude of the company leader, i.e., perceived rate of the importance of marketing (marketing importance); various marketing skills - but mainly marketing communication skills; as well as market orientation. Utilizing the characteristic groups of Deschoolmeester and Izquierdo (2008), the answer to the question "To what extent do SMEs apply different marketing solutions", i.e., what are the influencing factors that affect to what extent SMEs apply either classic or innovative online marketing solutions or social media marketing tools, was sought.

Based on the relevant considerations of the literature, there is a relationship between the influencing factors and the rate of SME marketing use. Consequently, RQ1-RQ5 focus on the research of these relationships.

[RQ1]: To what extent does an SME apply marketing solutions as a function of its entrepreneurial orientation?

Expectations in connection with [RQ1]: The application of different marketing solutions often entails a risk-taking behavior. Risk taking, or risk tolerance, is one of the most important entrepreneurial characteristics. It is expected that the higher the level of the SME leader's risk tolerance and willingness to innovate (entrepreneurial orientation), the higher the rate of application of the different classic, online, and social media marketing solutions used (Kraus, Harms \& Fink, 2010). In an organizational context, the rate of application of different IT solutions correlates with the leader's willingness to innovate (Scott \& Walczak, 2009).

[RQ2]: To what extent does an SME apply marketing solutions as a function of its ability to adapt to the market?
Expectations in connection with [RQ2]: The ability to recognize and take advantage of opportunities is regarded as a central element of entrepreneurship (Timmons, 1999). It is a foundational factor for SME leaders, without which it is not clear which opportunities the SME might realize. If company leaders cannot see any further than bringing the use of proven tools to the fore, then it is more difficult for them to take advantage of new business opportunities (Cyert \& March, 1992). Relying on the relevant considerations of the literature, it was expected that the more an SME leader recognizes business opportunities and adapts to the rapidly changing market conditions (ability to adapt), the more frequently they will use different classic, online, and social media marketing solutions.

[RQ3]: To what extent does an SME apply marketing solutions as a function of the leader's perception of marketing importance?

Expectations in connection with [RQ3]: Moorman and Rust (1999) explained the significant role of marketing in the organization, as a role recognized by everyone in the enterprise and applied in the form of various marketing tools. This essentially embodies the expectation that the higher the perceived importance of marketing, the more typical the intensity of the application of different classic, online, and social media tools.

[RQ4]: To what extent does an SME apply marketing solutions as a function of its marketing communication skills?

Expectations in connection with [RQ4]: Based on the relevant considerations of the literature (Carson \& Gilmore, 2000), there is a relationship between the SME leader's communication skills and the nature of the application of marketing solutions. A positive correlation was expected in this research with a higher level of marketing communication skills as a precondition for the use of different marketing tools.

[RQ5]: To what extent does an SME apply marketing solutions as a function of its market orientation?

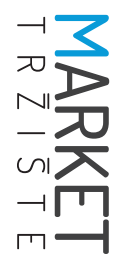


Expectations in connection with [RQ5]: To measure the correlation between market orientation and marketing activities, the measuring dimensions of Narver and Slater (1990) were used. A positive correlation between market orientation and the use of marketing tools was expected (Farrell, Oczkowski \& Kharabsheh, 2008; Péter, Keller \& Kaszás, 2013).

\section{METHODOLOGY AND SAMPLE CHARACTERISTICS}

In the qualitative stage of this study, research methods suggested by the literature were applied. Research on SMEs typically takes the form of case studies, opinions of the owner/manager, and status reports. A methodology should be capable of revealing the underlying causes of the individual behavior of SME leaders and/ or marketing specialists dealing with marketing and, subsequently, of exploring behavioral patterns that are testable using further (e.g., quantitative) methodologies. Using qualitative indepth interviews, our analysis was conducted in an explorative way as no primary empirically tested model existed in the literature that could have been applied to the research problem.

\subsection{Qualitative in-depth interviews}

The approaches found in scientific articles that deal with the marketing activity of SMEs are mainly of a qualitative and descriptive nature (Otero-Neira, Lindman \& Fernández, 2009; Nwankwo \& Gbadamosi, 2011) and are rarely tested in practice. Scientific papers and results in the field of SME marketing offer only partial insights into the responses to the research questions; therefore, the application of qualitative research methodology is essential to explore the theoretical relationships (Fillis, 2002; Otero-Neira, Arias \& Lindman, 2013). In the present case, the understanding relates to the marketing activity carried out by SMEs, its influencing factors, and its contribution to the overall marketing activity.
An in-depth interview is one of the most suitable tools to map individual behavior (Berg \& Lune, 2012). In this research study, a type of indepth interview - the key informant interview - was used. Key informant interviews are usually conducted with company leaders or specialists in a certain field, where the aim is to get to know the opinions of individuals who are particularly well-qualified in the research topic. Subjectivity and the role of personal experiences (Maxwell, 2008: p. 224-225) can help to confirm the research problem by means of theory. Through this confirmation, more useful insights, more precise research questions, and more valid measures are available. The aim of our in-depth interview research was to explore the marketing-related decision-making of SMEs.

In the case of reliability, the biggest concern is that the measurable factors change during multiple data collections. Nevertheless, if qualitative methodologies are applied, the individual pattern of understanding of the researcher involved is part of the research process. The subjectivity of the interviewer's opinion can be compensated by the use of several interviewers (King, 1994). In this article, the individual sensibility of the researcher was important, as a sovereign analysis was created thanks to it.

In the case of qualitative analysis, the main criterion of validity is the suspicion that we are not right (King, 1994). In the case of qualitative analysis, the verification of the validity of interpretations (explanations) is the main aim, i.e., whether the researcher's conclusions about a topic unfold from an interview and can be interpreted as valid or not. To decide this, several experts were consulted before conducting indepth interviews in this research. These experts helped establish whether the topics examined were really the ones that were meant to be the subjects of this research (inter-subjective test, King, 1994: p. 32).

According to King (1994), Healy and Perry (2000), and Maxwell (2012), further analysis of validity in the case of in-depth interviews was applied in this research: 
- Excluding imprecise and missing data: These were excluded by analyzing the transcribed interview corpus. No fragmentary memories or inaccurate notes were applied, rather the whole corpus, containing the whole, recorded interview was used.

- Avoiding problems of interpretation, and the error of forcing the researcher's views on the interview subjects: Open-ended questions were used, giving space to the interview subjects' own interpretations and avoiding the obligate/compulsory categorization to gain an understanding of the information gathered from interviewees.

- $\quad$ Avoiding the wrong interpretation of theory, considering different mind-sets: The sovereign opinion and mind-set of every interview subject were considered with a view to avoiding formulating vague and abstract suggestions.

\subsection{Sampling process and data preparation}

During the qualitative study, all Hungarian SMEs were considered a population that could apply online marketing tools for their operations. Based on our definition, an SME employs fewer than 250 people, has a maximum annual net turnover and balance sheet totals of EUR 40 million and EUR 43 million, respectively. Any company which meets the criterion of independence [other companies can have a maximum of $25 \%$ ownership in the SME studied] (EC, 2005; EC, 2009) was also included. Each SME selected was called an observation unit. During the empirical research process, the necessary information was provided by company leaders (owners, managing directors, store managers, etc.), and marketing specialists (unit of account).

There was no justification for random sampling as firms that could apply online marketing tools were sought, so non-random sampling was used. Within this category, snowball sampling was selected and using the snowball method, interview subjects were found by means of recommendations. The possible - but consciously handled - limitations of this methodology include the possibility that sample subjects are somehow connected to each other, giving rise to a greater chance of similarities. During the in-depth interviews, this situation was handled in the following way: attempts were made not to misinterpret similar phenomena as common behavioral patterns. The saturation of the sample size in this case - according to the work of Guest, Bunce and Johnson (2006) - occurred after 15 enterprises. The acceptable number of observation units in the sample, from the point of view of both the thematic and the theoretical saturation, was also established according to the definitions by Mason (2010), as well as Wilson and Coakes (2014: 150). Therefore, the final sample size in the qualitative phase was 15 SMEs.

To ensure perceived anonymity, the interviewees' names and contact data were treated confidentially. Interviewees are therefore referred to by their unique identifier (ISX, where $I S=$ interview subject; $X=1,2,3$, etc.). The duration of the interviews ranged from 30 to 90 minutes. Due to the nature of the research problem, face-to-face interviews were conducted with the help of an interviewer who could help respondents interpret the more difficult questions. By company size, the sample subjects were SMEs, while by market type, they included a mix of end-consumer and inter-organizational market representatives. Some respondents (IS2, IS4, IS7, IS14) were SMEs and marketing consultants, so in their quotes the term "they" relates to the SMEs that they work for and that receive marketing services from them. Sample characteristics are presented in more detail in Table 1.

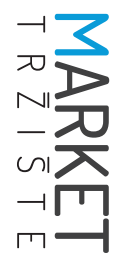


TABLE 1: Sample characteristics of the in-depth interview research $(N=15)$

\begin{tabular}{|c|c|c|c|c|}
\hline $\begin{array}{c}\text { Interview } \\
\text { subjects' } \\
\text { identifier }\end{array}$ & Interviewee's title & $\begin{array}{c}\text { Size } \\
\text { category } \\
\text { of the SME }\end{array}$ & $\begin{array}{c}\text { Type of the } \\
\text { market the SME } \\
\text { serves (in order of } \\
\text { importance) }\end{array}$ & $\begin{array}{c}\text { Industry sector } \\
\text { of the SME }\end{array}$ \\
\hline IS1 & Managing director & $\begin{array}{l}\text { Medium- } \\
\text { sized } \\
\text { enterprise }\end{array}$ & Inter-organizational & Manufacturing \\
\hline IS2 & Marketing consultant & $\begin{array}{c}\text { Small } \\
\text { enterprise }\end{array}$ & $\begin{array}{l}\text { End consumer / } \\
\text { Inter-organizational }\end{array}$ & Other services \\
\hline IS3 & Managing director & $\begin{array}{c}\text { Small } \\
\text { enterprise }\end{array}$ & $\begin{array}{l}\text { End consumer / } \\
\text { Inter-organizational }\end{array}$ & $\begin{array}{l}\text { Accommodation } \\
\text { and food service }\end{array}$ \\
\hline IS4 & Marketing consultant & $\begin{array}{c}\text { Small } \\
\text { enterprise }\end{array}$ & $\begin{array}{l}\text { End consumer / } \\
\text { Inter-organizational }\end{array}$ & Other services \\
\hline IS5 & Managing director & $\begin{array}{c}\text { Small } \\
\text { enterprise }\end{array}$ & Inter-organizational & IT \\
\hline IS6 & $\begin{array}{l}\text { Digital and client service } \\
\text { director }\end{array}$ & $\begin{array}{l}\text { Medium- } \\
\text { sized } \\
\text { enterprise }\end{array}$ & Inter-organizational & IT \\
\hline IS7 & Marketing consultant & $\begin{array}{c}\text { Small } \\
\text { enterprise }\end{array}$ & $\begin{array}{l}\text { End consumer / } \\
\text { Inter-organizational }\end{array}$ & Other services \\
\hline IS8 & Marketing manager & $\begin{array}{l}\text { Medium- } \\
\text { sized } \\
\text { enterprise }\end{array}$ & Inter-organizational & IT \\
\hline 159 & $\begin{array}{l}\text { Managing director, Creative } \\
\text { director }\end{array}$ & $\begin{array}{l}\text { Medium- } \\
\text { sized } \\
\text { enterprise }\end{array}$ & $\begin{array}{l}\text { Inter-organizational / } \\
\text { End consumer }\end{array}$ & IT \\
\hline IS10 & Managing director & $\begin{array}{l}\text { Medium- } \\
\text { sized } \\
\text { enterprise }\end{array}$ & $\begin{array}{l}\text { Inter-organizational / } \\
\text { End consumer }\end{array}$ & IT \\
\hline IS11 & Managing director & $\begin{array}{c}\text { Small } \\
\text { enterprise }\end{array}$ & $\begin{array}{l}\text { Inter-organizational / } \\
\text { End consumer }\end{array}$ & $\begin{array}{l}\text { Trade and car } \\
\text { repair }\end{array}$ \\
\hline IS12 & Marketing manager & $\begin{array}{c}\text { Small } \\
\text { enterprise }\end{array}$ & $\begin{array}{l}\text { Inter-organizational / } \\
\text { End consumer }\end{array}$ & $\begin{array}{l}\text { Trade and car } \\
\text { repair }\end{array}$ \\
\hline IS13 & Managing director & $\begin{array}{c}\text { Small } \\
\text { enterprise }\end{array}$ & $\begin{array}{l}\text { End consumer / } \\
\text { Inter-organizational }\end{array}$ & Other services \\
\hline IS14 & Marketing consultant & $\begin{array}{c}\text { Small } \\
\text { enterprise }\end{array}$ & $\begin{array}{l}\text { End consumer / } \\
\text { Inter-organizational }\end{array}$ & Other services \\
\hline IS15 & Managing director & $\begin{array}{c}\text { Small } \\
\text { enterprise }\end{array}$ & $\begin{array}{l}\text { End consumer / } \\
\text { Inter-organizational }\end{array}$ & $\begin{array}{l}\text { Accommodation } \\
\text { and food service }\end{array}$ \\
\hline
\end{tabular}

Source: own elaboration

The interview texts were cleaned and formatted giving a research corpus that formed the basis of the qualitative phase after data cleansing. The interviews were conducted according to an interview outline. Data analysis was carried out using a coding technique, where the codes were related to the SME marketing presented in the literature review and its influencing factors. 


\section{QUALITATIVE ANALYSIS}

Research questions were examined with the help of qualitative data analysis. The exploratory in-depth interviews helped to clarify the research questions that were established based on the literature review and to adapt them to the research problem.

\subsection{Interpretation of the marketing activity}

Marketing appears in various aspects of interpretation in the life of the 15 SMEs included in the research. Even though the majority of scientific definitions provide assistance in interpreting the notion of marketing activity (Simpson, Padmore, Taylor \& Frecknall-Hughes, 2006; Gamble et al., 2011), more light needs to be shed on the particularities related to the SME context which were regularly mentioned by the interviewees (intuitive, spontaneous, less conscious and are largely dependent on the leader's attitude and the perception of the importance of marketing) (Reijonen, 2010; O'Donnell, 2011). It seems that in certain cases the interpretation of marketing activity at SME level is associated with the sales activity. This pattern is in line with the related literature that essentially states that, due to size constraint in the case of SMEs, marketing activity in the broad sense is tendentiously invisible or has not yet taken shape even though there is always a product or a service which has to be taken to the target group (Molenaar, 2012); for this, sales are indispensable, thus their role is not negligible either:

In the SME sector, these two things (marketing and sales) are intertwined and even many medium-sized enterprise leaders do not have proper information on the difference between sales and marketing. (IS2)
In a broader sense, based on the opinions of the interviewees, marketing can be equal to the process of customer acquisition, where the acquisition of new customers, the retention of existing ones, and in certain cases the customer education are included (Molenaar, 2012).

Of course, besides the basic meaning of marketing, several additional factors are mentioned in relation to the fundamental existential conditions of marketing in a broader sense (e.g., customer acquisition).

Unfortunately [...] we lose customers, whose replacement is of key importance, and marketing has a great importance in this. (IS7)

One such factor is the issue of the leader's attitude (Aaltonen, 2013), which, based on the opinions of the interviewees, may have a strong influence on the nature of the marketing activity. In the interpretation, if marketing is considered to be an important element in the life of an $S M E$, the given firm will presumably apply various marketing-related tools and activities in a different way. Linked to this is a managerial SME approach (Mort et al., 2012), which is ideally sufficiently far-sighted (long-term) to produce results and according to which marketing is not just an expensive "burden" requiring large capacities, but something that can be a substantial condition for the basic operation of the SME. This is interpreted as the perception of marketing importance, which is explained in the next section on the importance of marketing. The interpretation of the marketing activity is explained in detail in Figure 1. The more narrow or broader interpretations of the concept the interviewees provide during their own phrasing, the broader the area of the interpretive figure will be, an area thus greatly influenced by the leader's attitude (Fu, 2011; Durkin et al., 2013).

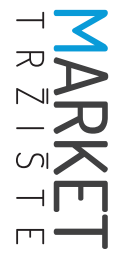


FIGURE 1: Interpretation of the marketing activity by SMEs ( $\mathrm{N}=15)$

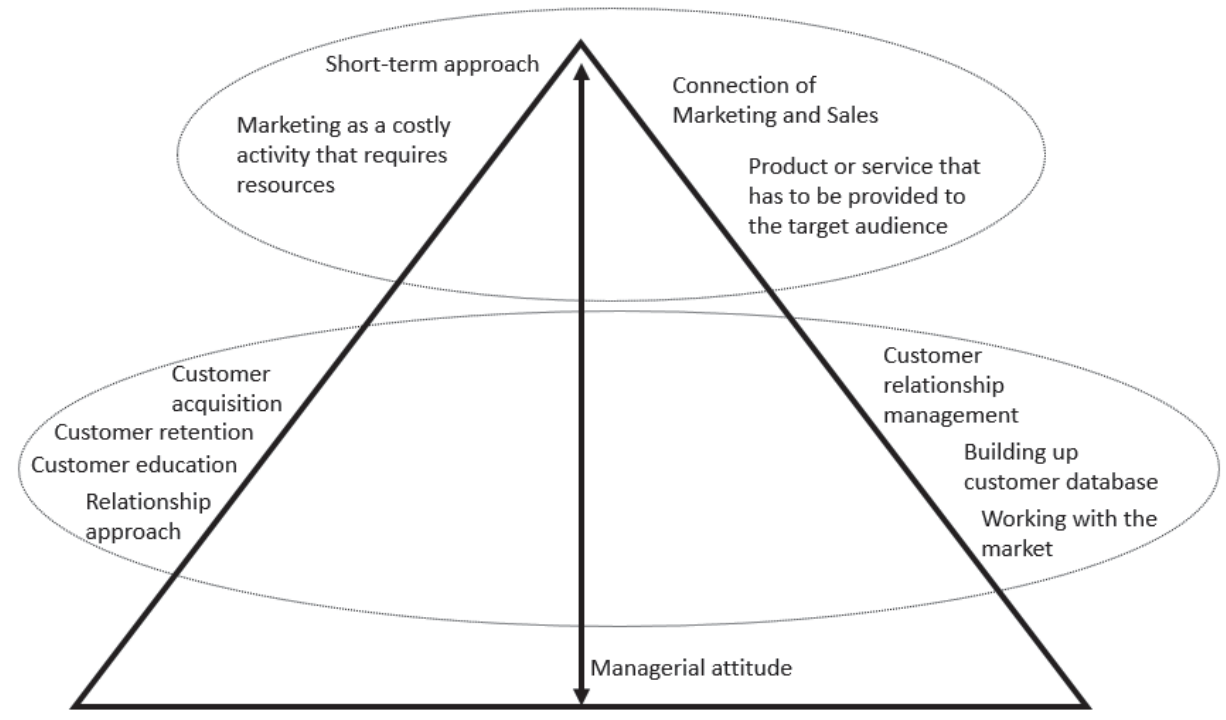

Source: own elaboration

\subsection{Importance of the marketing activity}

The mention by the interviewees of marketing as a forced activity is interesting because the recognition of the "need" or interest (i.e., when managers become aware of the lack of a marketing activity at their firm) can also lead to the more intensive use of marketing tools, just like any innovation skill or market adaptation ability (Hooley et al., 2005). Interestingly, that does not necessarily match the literature (Hooley et al., 2005). It is not the higher profit, the greater marketing or corporate performance which determines the intensity of the marketing activity in an SME, but rather necessity. Respondents mentioned "well-understood economic interest", which in this sense is a basic need in an SME. If the SME recognizes it, this alone does not suffice for success but can lead to it, becoming a competitive advantage and shifting to a higher level in the life of an enterprise.

The reason I deal with marketing is not because it is my hobby. It is simply in our well-understood interests. Economic interest is something which is either recognized or not. If it is recognized, the firm will move in the right direction, in terms of marketing, product development, technology development, warehousing, or any other aspect. But if the economic interest is not well-recognized - which may happen in some cases - the company will be at a standstill or will move in the wrong direction. (IS11)

Marketing activity is mentioned in the in-depth interviews as an element of major importance, one that plays a role in the creation of good image and reputation of the SME in the market. Mentioning other basic activities (management, finance, human resources, product policy) together with marketing is an attitude that cannot be ignored, because it explicitly - not in any latent form or from a few uttered words but clearly and intelligibly - indicates that marketing can be at the same level as other basic corporate functions (Kottika, Stathakopoulos \& Theodorakis, 2013). In certain cases, it even plays a key role and has special functions compared to other basic activities (Figure 2). A tendency can be observed, namely, that the given enterprise seems more likely to use marketing tools than those SMEs which are skeptical about marketing. 
[...] if I have to mention the basic pillars of the company, these are the product, marketing, finance, management, and HR. Roughly speaking, we need to stand on these five stable legs, and if any of them breaks off, the company will tilt. (IS3)

Based on the interviews, marketing training shows what value marketing has for an SME. Marketing training appears in two dimensions: (1) marketing skills can be a must for the performance of the marketing function (recruitment selection criteria); and (2) the recognition and explicit need for vocational training for the person responsible for the firm's marketing functions can help recognize the importance of marketing.

Based on the interviews, market sensitivity or customer focus can be interpreted as another influencing element. This recognition can make the transition from the production-oriented organizations focusing only on internal return, to customer-oriented organizations focusing on the market they primarily strive to serve. The recognition of the importance of the marketing function may be associated with the or- ganization's recognition of the conditions of a market-oriented operation, i.e., highlighting the importance of the customer's opinion in decision-making (Aaltonen, 2013).

It was pretty hard to get my production manager to accept that he should ignore that he thinks it is good. It is not about his opinion that it is good; it is about the customers' opinion that the product is good. (IS12)

In the case of the 15 SMEs studied, where targeting a niche market is of primary importance because of the burdens and characteristics mentioned in the literature review (Zortea-Johnston et al., 2012), a market-oriented behavior can also be realized in a more focused way (Figure 2). The higher-level dimensions - like market orientation or customer focus - appeared much more implicitly than consciously during the interviews. In many cases, the interviewees almost "realized" the interconnection between market-oriented behavior and the marketing function, which became clear later, during the analysis phase.

FIGURE 2: Importance of the marketing activity by SMEs ( $\mathrm{N}=15)$

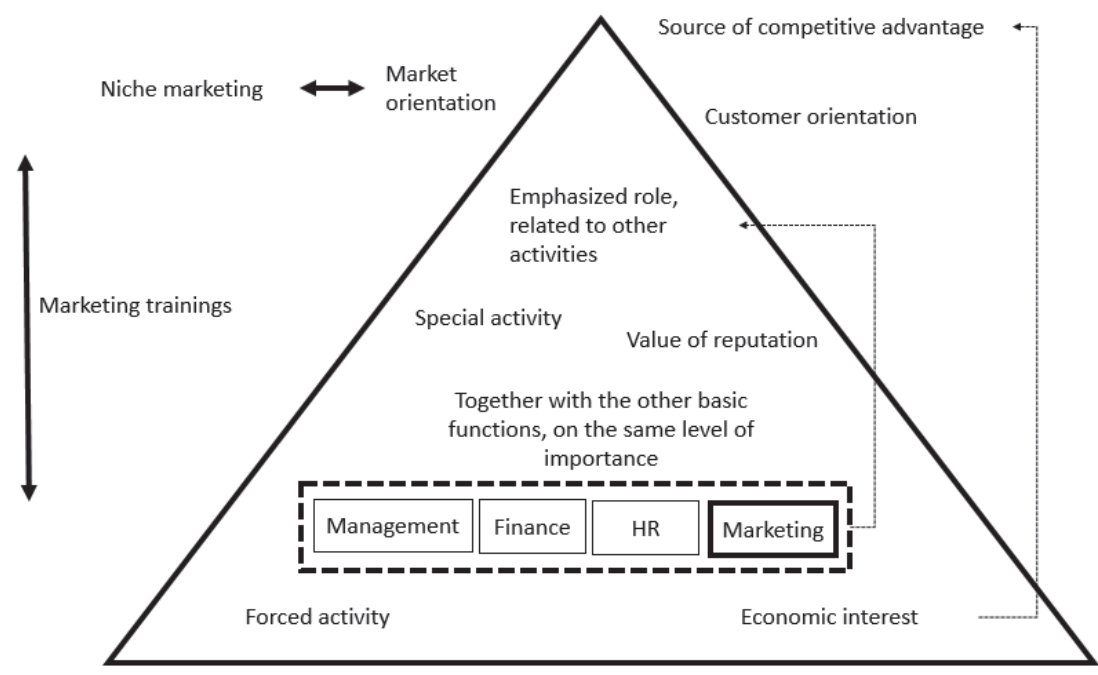

Source: own elaboration 


\subsection{Personal responsibility for the marketing activity}

The patterns seen in the field of SME marketing (Fillis, 2003) can also be found in the qualitative results of our study. The lack of awareness seen from the interviews can affect marketing as a whole; this approach may occur in many cases among the SMEs of the sample.

Small and medium-sized enterprises believe that if they have, say, ten subscribers, they will have ten customers. (IS6)

Another such potential burden is a strong influence of the SME leader (Mort et al., 2012). In small firms, the managing director or the owner either cannot afford to hire a marketing specialist as an employee, or if they can - i.e., if the company is over a certain size - the transfer and sharing of responsibility can be difficult. The strong influence of the SME leader was reflected during the interviews in situations such as hindering the recruitment of a marketing specialist employee, or disparaging or marginalizing the whole profession.

Although marketing activity is an important function, either at an implicit or an explicit level, the recognition of marketing as a discipline can be problematic. Because of their different mind sets, the co-operation between the SME leader and a member of staff responsible for marketing (or marketing agency) often cannot be established. However, there is the argument that SMEs know their actual business, while the marketing profession does not have these fundamental knowledge elements (Durkin et al., 2013).

This guy felt for a long time that he was working only if his table was piled high with papers, and he kept an eye on everything. So this was actually his perception, that he controls the organization if he is asked about everything and he answers everything, and then the organization will operate well. (IS2)

Marketing is in my hands, so I consider it to be an important thing which I do not think I can let out of my hands for now. Obviously, this depends on the given person, so if there was a suitable person, I would be happy to do that. But I think it is an important thing that I will not really let out of my hands. (IS3)

In this sense - based on the interviewees' opinions - the SME leaders, who possess specialist knowledge, risk by entrusting this declaredly important function to a marketing employee or else they engage in marketing themselves, in many cases with "top-heavy" control. As a result, the SME leader must take responsibility for making more mistakes with the newly acquired generalist knowledge of marketing than would be made by a professional marketing specialist employed as a result of a good selection process. Even though marketing usually requires more specific knowledge and new skills and often involves IT experts, it seems that SME leaders do it themselves, with all the possible negative consequences that may arise as a result. In this respect, the existence of training with a marketing focus, self-education, material from "marketing gurus", and other forms of training suggest that SME leaders should not acquire their marketing profession-specific knowledge by themselves. It can be concluded that it is not the dimensions themselves which are interesting from the analytical point of view but the tensions and overlaps between them, as well as the existence of the marketing skills that can repeatedly connect the various thinking thought patterns, and also the employees with generalist and specialist knowledge in an SME (Morgan, 2012).

In case he does happen to afford to employ a relatively good expert, and this good expert is obliged to go there for a very low salary - which sometimes happens, he will not let him do his job. And the management is arrogant enough to believe that they are good at everything. [...] And this is what will actually constrain them. (IS4)

They would really like to acquire the expertise these people have, but they cannot afford or do not want to pay this amount of money because they think that the professional knowledge... acquired in 
five or ten years in a firm is a sort of pseudoscience. These people are false, self-deceptive, and comfortable. (IS14)

\subsection{Online marketing communication and its success}

As evidenced in our sample, a kind of openness to online marketing - since online marketing communication is said to ensure an excellent opportunity for measurability, efficiency, and cost-effectiveness (Aaltonen, 2013) - can be observed in certain SMEs. Furthermore, market pressure also appears to "impose" the application of recent trends on enterprises. At the same time, resource constraints (e.g., money, time, and human resources, see Fillis, 2003) can often put an end to the online manifestations of marketing communication, even if it seems that there is an explicit need for these solutions.

They [SMEs] would like to be online very much; they feel that it is really necessary, they can see that they should do it. Consequently, they are totally out of touch with it, just like most SMEs. (IS7)

In these cases, sectoral and market-type issues explicitly separate the manifestations of the various SMEs from each other. We can see a kind of duality, which separates manufacturing enterprises from service providers. According to the experiences of the interviewees, service provider firms operating at the end-customer markets may demonstrate a rich assortment of online marketing use; at the same time, it can be seen that manufacturing enterprises have completely different needs where a company brochure-like web page may ensure a sufficient function for the enterprise, while a restaurant or a technology-oriented IT SME may already be driven to try innovative online marketing solutions too. The interviewees' answers reflect well the conclusions found in the literature (O'Sullivan \& Abela, 2007; Homburg, Artz \& Wieseke, 2012), which emphasize the importance of the role of the sector in the use of online marketing.

The production of doors and windows is a topic just like that, beauty and health is a topic like that, baby products is a topic like that, and I could tell you a few more regardless of whether it is a small enterprise, it is totally focused on online. You do not have to explain this to them. (IS5)

To some extent, it is important for production companies, but the possibilities are limited. (ISI)

Of course, we can create a nice website for a concrete plant, but that is all. Maybe we can make a form too which you must fill out if you want to send your enquiry. (IS9)

Mobile marketing showed up as an interesting element in the interviews because it is not actually a marketing communication tool but rather a platform or channel through which, albeit with certain modifications, it is possible to apply the same display advertising, search engine marketing, email newsletters, or other classic online advertising tools (Maduku, Mpinganjira \& Duh, 2016). Therefore, its role may become increasingly important with the spread of mobile devices. Users increasingly search for the products or services of a given enterprise on their mobile devices. According to the interviewees, this recognition encourages many SMEs to try to keep up with global trends and use a set of mobile marketing communication tools. But while these solutions are often promising, according to the interviewees, in at least the same number of cases they are unaffordable.

The social media marketing communication toolset is broad, so countless platforms are available for SMEs within this toolset (Dahnil, Marzuki, Langgat \& Fabeil, 2014). Nevertheless, especially in Hungary, it is the social networking sites, mainly Facebook, which have spread the most. This platform and its opportunities were typically mentioned during the in-depth interviews. Considering Facebook in a marketing communications perspective is a complex issue. Due to the ever-changing advertising conditions, there was no common position among the interviewees about its efficiency. However, the possibility of allowing consumer opinions via social media is already a business opportunity for SMEs that may be connected with the

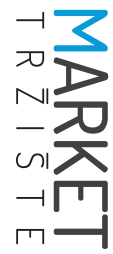




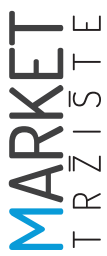

perspective of establishing customer social networks. Here, of course, it is worth mentioning that the direct connection of social media and sales is not always a fortunate objective. Therefore, based on the interviewees' opinions, other aspects may play a greater role in the application of social media by SMEs (image-building, improvement of brand image towards the market vs. direct response-type campaigns). While other tools - micro blogging services (Twitter), blogs, content sharing sites - may occur in certain business niches, they are not widely used nor is their use typical for Hungarian enterprises. Possible reasons given by interviewees include influencing factors, together with the enabling and inhibiting factors of online and social media marketing. The skills that are mainly related to marketing communication, risk-taking entrepreneurial behavioral patterns, and market adaptation were all factors mentioned by respondents (see Akunuri, 2011):

If you are a more technological, geek start-up company, and you spend your whole weekend browsing on Google, then it is conceivable that you can set a campaign for yourself. (IS5)

A man who comes from the marketing profession, or especially from the field of PR or branding, is not used to and does not accept that you change what you do, what you optimize with and together with this a part of the indicators, within one year. Do you understand it? Then it is the category of juggling and then it is a kind of black box. (IS6)

The recognition of the importance of new trends is increasingly obvious in SME niche markets:

Online marketing cannot be avoided, especially in the SME sector. (IS2)

Nevertheless, the limiting factors of the small Hungarian market or the general reluctance and fear concerning the marketing activity in general that were mentioned by interviewees should be considered; in the absence of entrepreneurship orientation and market adaptation, this may limit the success of online and social media marketing solutions, too.
They simply get frightened by Facebook, not to mention the people's abuse and fight in a forum from '92 on Reddit, and they do not understand why it would work. (IS2)

\section{CONCLUSIONS}

As a result of the research, based on the answers obtained from the interviewees, some recurring patterns were found which helped us grasp a better understanding while interpreting the marketing function in the SME sector. In the case of companies that are this particular size, sales and marketing are closely linked and treated together. The scope of interpretation of marketing is narrowed to the two-fold task of customer acquisition and customer retention (Molenaar, 2012). By examining the definition that delineates SME marketing from that of larger enterprises, we conclude from this qualitative study that marketing practice operates with limited resources and under strong managerial control, typically satisfying niche market aims (Gamble et al., 2011; Durkin et al., 2013).

In connection with the influencing factors, it is interesting to note that the leader's role as an influencing factor was mentioned several times during the interpretation of the marketing function, supporting the idea that the perception of the importance of marketing is typically defined by the company leader's attitude (Mort et al., 2012; Durkin et al., 2013) (RQ3). Besides, company leaders imply the use of different online and social media marketing solutions, and if there are many innovative employees in the organization, but the manager is not ready to apply a professional social network to attract business partners and generate possible leads for example, then the final decision by the SME leader will not go through. With respect to that, marketing communication skills of innovative SME managers seem to be important in the application of online and social media marketing tools (RQ4).

When emphasizing the role of marketing, customer focus (customer orientation) appears as 
an influencing factor (Zortea-Johnston et al., 2012) (RQ5). Thus, the basic orientation of the SME to its target segments also seems to influence the use of different online and social media marketing tools. If the customers have a need for innovative solutions and the SME recognizes this need, then its marketing decisions will reflect that. The analysis of personal responsibility in the marketing function helps us see the important role of SME leaders in decision-making and in the application of marketing tools. Market adaptation (RQ2) and innovativeness (entrepreneurship orientation) (RQ1) are mentioned in some form as influencing factors of the marketing activity (O'Sullivan \& Abela, 2007; Homburg et al., 2012). The ability to better adapt to the market is usually a matter of flexible operation, as a reaction to market changes, and if the market needs online customer management or up-to-date forum services, then the SME should respond quickly to these needs. Innovativeness and entrepreneurship orientation are closely connected to online and social media marketing, hence without new, sometimes risky, but prospective thoughts and activities, innovative marketing solutions cannot be implemented into an SME's operations.

The common openness of SMEs to online marketing activities is evident. Yet, at the same time, the negative consequences of limited resources were also mentioned. Online marketing activities have different roles by sector and market type (typically, end-customer and inter-organizational markets are separated). An online presence is more typical of certain sectors (e.g., $I T$, services), but the emphasis on marketing activities can be completely different in the case of manufacturing companies. An exciting field of the analysis is the question of how much the use of Internet-based technologies for marketing purposes depends on the innovative nature and attitude (RQ1) of the SME (Maduku et al., 2016). In many cases, the "well-understood economic interest" is also mentioned as if it "forced" the company leader to apply new technologies (e.g., mobile marketing). However, necessity does not equal knowledge. When applying new technologies and innovative solutions, there is no guarantee that these tools will be applied properly or in a professional way, going beyond mere buzzwords (e.g., online marketing, mobile marketing), without a thorough understanding of marketing. In the interviews, it was mentioned several times that marketing specialists and responsible SME leaders speak about online solutions in different terms and that they have exaggerated expectations concerning them. Regarding social media marketing, Hungarian enterprises typically mention Facebook during their concept association, which can be explained by the limitations of the Hungarian market. Niche markets (e.g., IT) are also mentioned where certain services are successful within their own market segment. This confirms the advantages of targeting niche markets in online marketing, which can create rich opportunities for SMEs (Gamble et al., 2011; Durkin et al., 2013). Social media marketing can be a relevant tool for SMEs since it allows the delivery of opinions, but the measurement of direct performance cannot always be carried out easily at the same time (Michelidou et al., 2011).

In sum, it can be stated that the research questions were partly verified, and in the case of several influencing factors, important connections concerning marketing activity in SMEs were explored with the help of qualitative methodology.

With regard to the relevant literature, Bocconcelli and others (2017), for example, explored the impact of social media on an analyzed SME. In our study, we analyzed the connection among different decision-making elements and marketing tools (online and social media).

The research has several limitations. As mentioned earlier, sample size could be increased, and sample structure improved in the future by having a specific group of respondents (e.g., by industry or market type) in the sample and by analyzing their marketing decisions specifically. Qualitative research findings are not generaliz-

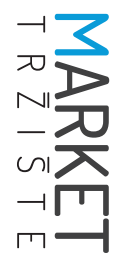


able, so a quantitative survey could be conducted on a larger sample to analyze the hypothesized connections of the constructs observed.
In the future, wider data collection could be carried out to analyze the situation not only in Hungary, but in other countries as well.

\section{References}

1. Aaltonen, H. (2013). Implementing entrepreneurial marketing in SMEs. EMAC $42^{\text {nd }}$ Annual Conference, Istanbul, June 4-7, 2013.

2. Akunuri, J. (2011). Internet Marketing. In: S. Nwankwo \& A. Gbadamosi (eds.), Entrepreneurship Marketing - Principles and Practice of SME Marketing. Oxfordshire: Routledge.

3. Andzulis, J. M., Panagopoulos, N. G., \& Rapp, A. (2012). A Review of Social Media and Implications for the Sales Process. Journal of Personal Selling \& Sales Management, 32(3), 305-316.

4. Berg, B. L., \& Lune, H. (2012). Qualitative research methods for the social sciences. New Jersey, NJ: Pearson Education Inc.

5. Blackburn, R. A., Hart, M., \& Wainwright, T. (2013). Small Business Performance: Business, Strategy and Owner-Manager Characteristics. Journal of small business and enterprise development, 20(1), 8-27.

6. Bocconcelli, R., Cioppi, M., \& Pagano, A. (2017). Social Media as a Resource in SMEs' Sales Process. Journal of Business \& Industrial Marketing, 32(5), 693-709.

7. Bocconcelli, R., Cioppi, M., Fortezza, F., Francioni, B., Pagano, A., Savelli, E., \& Splendiani, S. (2016). SMEs and Marketing: A Systematic Literature Review. International Journal of Management Reviews, 20, 1-28.

8. Bodlaj, M., \& Rojšek, I. (2014). Marketing in Small Firms: The Case of Slovenia. Economic and Business Review for Central and South-Eastern Europe, 16(2), 101-119.

9. Buzulukova, E. (2013). The key role of entrepreneurship orientation in small and medium-sized enterprises' performance. EMAC 42 ${ }^{\text {nd }}$ Annual Conference, Istanbul, June 4-7, 2013.

10. Carson, D. J., \& Gilmore, A. (2000). SME Marketing Management Competencies. International Business review, 9(3), 363-382.

11. Covin, J. G., \& Slevin, D. P. (1989). Strategic Management of Small Firms in Hostile and Benign Environments. Strategic Management Journal, 10(1), 75-87.

12. Cyert, R., \& March, J. G. (1992). A behavioural theory of the firm. Oxford: Blackwell.

13. Dahnil, M. I., Marzuki, K. M., Langgat, J., \& Fabeil, N. F. (2014). Factors Influencing SMEs Adoption of Social Media Marketing. Procedia-social and behavioral sciences, 148, 119-126.

14. Deschoolmeester, D., \& Izquierdo, E. (2008). What entrepreneurial competencies should be emphasized in entrepreneurship and innovation at the undergraduate level. In: R. de St-Gall \& U. Fueglistaller (eds.), Innovation, competitiveness, growth and tradition in SMEs (pp. 1-14). Verlag KMU: HSG.

15. Durkin, M., McGowan, P., \& McKeown, N. (2013). Exploring Social Media Adoption in Small to Medium-sized Enterprises in Ireland. Journal of Small Business and Enterprise Development, 20(4), $716-734$.

16. EC (2005). The new SME definition. User guide and model declaration. European Commission, Enterprise and Industry Publications. 1-52.

17. EC (2009). Commission staff working document on the implementation of Commission Recommendation of 6 May 2003 concerning the definition of micro, small and medium-sized enterprises. European Commission, Commission staff working document. 1-5.

18. Farrell, M. A., Oczkowski, E., \& Kharabsheh, R. (2008). Market Orientation, Learning Orientation and Organizational Performance in International Joint Ventures. Asia Pacific Journal of Marketing, 20(3), 289-308. 
19. Fehér, P. (2012). Integrating and Measuring Business and Technology Services in the Context of Enterprise Architecture. In: V. Shankararaman, J. Zhao \& J. Lee (eds.). Business Enterprise, Process, and Technology Management: Models and Applications (pp. 148-163). Hershey, PA: Business Science Reference.

20. Fillis, I. (2002). Small Firm Marketing Theory and Practice: Insights from the Outside. Journal of Research in Marketing \& Entrepreneurship, 4(2), 134-157.

21. Fillis, I. (2003). A Plea for Biographical Research as Insight into Smaller Firm Marketing Theory Generation. Journal of Enterprising Culture, 11(1), 25-45.

22. Fu, Y-K. (2011). Marketing Activities Management in SMEs: An Exploratory Study. Human Systems Management, 30(3), 155-166.

23. Gamble, J., Gilmore, A., McCartan-Quinn, D., \& Durkan, P. (2011). The Marketing Concept in the 21st Century: A Review of How Marketing has been defined since the 1960s. The Marketing Review, 11(3), 227-248.

24. Gruber, M. (2004). Marketing in New Ventures: Theory and Empirical Evidence. Schmalenbach Business Review: ZFBF, 56(2), 164-199.

25. Guest, G., Bunce, A., \& Johnson, L. (2006). How Many Interviews are enough? An Experiment with Data Saturation and Variability. Field Methods, 18, 59-82.

26. Gyulavári, T., \& Kenesei, Z. (2012). The Impact of Marketing Resources on Corporate Competitiveness. Market-Tržište, 24(1), 7-21.

27. Gyulavári, T., \& Kolos, K. (2015). The impact of proactive strategies on market performance in economic downturn: The case of Hungary. In: A. Diamantopoulos, B. B. Schlegelmilch, A. Schuh \& U. Wagner (eds.), Convergence and Divergence in the New Europe: Marketing Challenges and Issues. Proceedings of $6^{\text {th }}$ EMAC Regional Conference. Wien: University of Economics and Business.

28. Hansen, G. S., \& Wernerfelt, B. (1989). Determinants of Firm Performance: The Relative Importance of Economic and Organizational Factors. Strategic Management Journal, 10(5), 399-411.

29. Healy, M., \& Perry, C. (2000). Comprehensive Criteria to Judge Validity and Reliability of Qualitative Research within the Realism Paradigm. Qualitative Market Research: An International Journal, 3(3), 118-126.

30. Herrmann, P., \& Nadkarni, S. (2014). Managing Strategic Change: The Duality of CEO Personality. Strategic Management Journal, 35(9), 1318-1342.

31. Homburg, C., \& Pflesser, C. (2000). A Multiple-layer Model of Market-oriented Organizational Culture: Measurement Issues and Performance Outcomes. Journal of Marketing Research, 37(4), 449462.

32. Homburg, C., Artz, M., \& Wieseke, J. (2012). Marketing Performance Measurement Systems: Does Comprehensiveness Really Improve Performance?. Journal of Marketing, 76(3), 56-77.

33. Hooley, G. J., Greenley, G. E., Broderick, A. J., \& Rudd, J. M. (2004). Strategic Planning Differences among Different Multiple Stakeholder Orientation Profiles. Journal of Strategic Marketing, 12(3), 163-182.

34. Hooley, G. J., Greenley, G. E., Cadogan, J. W., \& Fahy, J. (2005). The Performance Impact of Marketing Resources. Journal of Business Research, 58(1), 18-27.

35. Kaszás, N., Péter, E., Keller, K., \& Kovács, T. (2016). Boundless Opportunities with Definite Limitations. DETUROPE: Central European Journal of Tourism and Regional Development, 8(1), 5-20.

36. King, N. (1994). The qualitative research interview. In: C. Cassel \& G. Symon (eds.), Qualitative Methods in Organizational Research - A Practical Guide (pp. 14-36). London: Sage Publications.

37. Kottika, E., Stathakopoulos, V., \& Theodorakis, I. (2013). Do Entrepreneur's Personality Traits Affect Market Orientation and Marketing Planning in Small Firms?. EMAC $42^{\text {nd }}$ Annual Conference, Istanbul, June 4-7, 2013. 
38. Kraus, S., Harms, R., \& Fink, M. (2010). Entrepreneurial Marketing: Moving beyond Marketing in New Ventures. International Journal of Entrepreneurship and Innovation Management, 11(1), 1934.

39. Maduku, D. K., Mpinganjira, M., \& Duh, H. (2016). Understanding Mobile Marketing Adoption Intention by South African SMEs: A Multi-Perspective Framework. International Journal of Information Management, 36(5), 711-723.

40. Malota, E. (ed.) (2015). Marketing on the International Scene, Cases from the Domestic and International Markets. Budapest: Alinea.

41. Mason, M. (2010). Sample Size and Saturation in PhD Studies Using Qualitative Interviews. Forum: Qualitative Social Research 11.

42. Maxwell, J. A. (2008). Designing a qualitative study. In: L. Bickman \& D. J. Rog (Eds.), The handbook of applied social research methods ( $2^{\text {nd }}$ ed.). (pp. 214-253). Thousand Oaks, CA: Sage Publications.

43. Maxwell, J. A. (2012). Qualitative Research Design: An Interactive Approach. Thousand Oaks, CA: Sage Publications.

44. Merrilees, B., Rundle-Thiele, S., \& Lye, A. (2011). Marketing Capabilities: Antecedents and Implications for B2B SME Performance. Industrial Marketing Management, 40(3), 368-375.

45. Michaelidou, N., Siamagka, N. T., \& Christodoulides, G. (2011). Usage, Barriers and Measurement of Social Media Marketing: An Exploratory Investigation of Small and Medium B2B Brands. Industrial marketing management, 40(7), 1153-1159.

46. Molenaar, C. (2012). E-Marketing - Application of Information Technology and the Internet within Marketing. New York, NY: Routledge.

47. Möller, K., \& Anttila, M. (1987). Marketing Capability - A Key Success Factor in Small Business? Journal of Marketing Management, 3(2), 185-203.

48. Moorman, C., \& Rust, R. T. (1999). The Role of Marketing. Journal of Marketing, 63, 180-197.

49. Morgan, N. A. (2012). Marketing and Business Performance. Journal of the Academy of Marketing Science, 40(1), 102-119.

50. Mort, G. S., Weerawardena, J., \& Liesch, P. (2012). Advancing Entrepreneurial Marketing. European Journal of Marketing, 46(3/4), 542-561.

51. Murphy, G. B., Celuch, K., \& Callaway, S. K. (2015). Small Business Internet Use and Strategic Flexibility. Journal of Small Business Strategy, 18(1), 57-68.

52. Narver, J. C., \& Slater, S. F. (1990). The Effect of a Market Orientation on Business Profitability. Journal of Marketing, 54(4), 20-35.

53. Nwankwo, S., \& Gbadamosi, A. (eds.) (2011). Entrepreneurship Marketing - Principles and Practice of SME Marketing. Oxfordshire: Routledge.

54. O'Donnell, A. (2011). Small Firm Marketing: Synthesizing and Supporting Wisdom. Journal of Small Business and Enterprise Development, 18(4), 781-805.

55. O'Sullivan, D., \& Abela, A. V. (2007). Marketing Performance Measurement Ability and Firm Performance. Journal of Marketing, 71(2), 79-93.

56. Otero-Neira, C., Arias, M. J. F., \& Lindman, M. T. (2013). Market Orientation and Entrepreneurial Proclivity: Antecedents of Innovation. Global Business Review, 14(3), 385-395.

57. Otero-Neira, C., Lindman, T. M., \& Fernández, M. J. (2009). Innovation and Performance in SME Furniture Industries: An International Comparative Case Study. Marketing Intelligence \& Planning, 27(2), 216-232.

58. Péter, E., Keller, K., \& Kaszás, N. (2013). Egészségtudatosság - része a szervezeti kultúrának?. Budapest Management Review, 44(6), 52-58.

59. Reijonen, H. (2010). Do all SME Practice Same Kind of Marketing?. Journal of Small Business and Enterprise Development, 17(2), 279-293. 
60. Scott, J. E., \& Walczak, S. (2009). Cognitive Engagement with a Multimedia ERP Training Tool: Assessing Computer Self-efficacy and Technology Acceptance. Information and Management, 46(4), 221-232.

61. Sidik, I. G. (2012). Conceptual Framework of Factors Affecting SME Development: Mediating Factors on the Relationship of Entrepreneur Traits and SME Performance. Procedia Economics and Finance, 4, 373-383.

62. Simpson, M., Padmore, J., Taylor, N., \& Frecknall-Hughes, J. (2006). Marketing in Small and Medium-sized Enterprises, International Journal of Entrepreneurial Behavior \& Research, 12(6), 361-387.

63. Timmons, J. A. (1999). New venture creation: Entrepreneurship for the $21^{1 t}$ century. Boston, MA: Irwin-McGraw-Hill.

64. Trainor, K. J., Andzulis, J. M., Rapp, A., \& Agnihotri, R. (2014). Social Media Technology Usage and Customer Relationship Performance: A Capabilities-based Examination of Social CRM. Journal of Business Research, 67(6), 1201-1208.

65. Vorhies, D. W., \& Morgan, N.A. (2005). Benchmarking Marketing Capabilities for Sustainable Competitive Advantage. Journal of Marketing, 69(1), 80-94.

66. Walsh, M. F., \& Lipinski, J. (2009). The Role of Marketing Function in Small and Medium Sized Enterprises. Journal of Small Business and Enterprise Development, 16(4), 569-585.

67. Wilson, N., \& Coakes, E. (2014). Business research. Enjoy creating, developing and writing your business project. London: Kogan Page Ltd.

68. Zortea-Johnston, E., Darroch, J., \& Matear, S. (2012). Business Orientations and Innovation in Small and Medium Sized Enterprises. International Entrepreneurship and Management Journal, 8(2), 145164.

\section{Endnotes}

1 The four conditions often occur simultaneously, but sometimes certain characteristic(s) represent(s) other companies, too (e.g., there are cases in which large companies have enough resources, though they lack specialist knowledge, the manager's power is constrained etc.). 